The Geneva Papers on Risk and Insurance, 17 (No. 65, October 1992), 443 - 445

\title{
The Law and Economics of Environmental Policy
}

\author{
by Michael G. Faure*
}

\section{Introduction}

This volume is the result of a cooperation between the European Association of Law and Economics (EALE) and the Geneva Association. Every other year these institutions co-organise a workshop on a topic in Law and Economics, which is equally of interest to the insurance world. On April 4 and 51991 such a joint conference was organised in Paris on the Law and Economics of Environmental Policy. Most of the papers in this issue were presented at this Paris conference: the papers by Rocard/Smets, Menell, Faure/Skogh and Fenn. In addition, one paper presented at the 8th Annual Conference of the EALE in Copenhagen was included as well, being the paper by Donald Dewees, since it fitted well in this issue on environmental policy. The reader will notice that the EALE and Geneva Association although they are European in origin have intense ties with North-American scholars as well. We are particularly pleased that Donald Dewees and Peter Menell agreed to submit their papers for publication in this issue. Thus the issue contains an interesting overview of some of the topics currently dealt with in the Law and Economics research on environmental policy, both in Europe and in North-America.

The first two papers deal with somewhat general problems of environmental law; the last three papers deal with more specific environmental problems such as municipal solid waste, liability for nuclear accidents and regulation of fishing.

Donald Dewees opens this issue with a paper of particular interest for Law and Economics research. It deals with the fundamental question whether environmental protection should be reached through the use of liability rules or by using safety regulation. In his seminal article on this topic Steven Shavell examined the comparative benefits of liability rules and safety regulation. He showed that in case of environmental damages tort rules would often lack a deterrent effect; therefore regulation which sets the environmental standards is required.

\footnotetext{
* Research Institute METRO, University of Limburg, the Netherlands.
} 
Dewees shows in his paper that civil litigation has not been a major cause of the substantial control of air- and waterpollution that has occurred since the middle of the century. In contrast, Dewees argues that government regulation has substantially reduced some pollution emissions. Thus Dewees provides important empirical evidence of Shavell's theoretical statement that environmental damages should be reduced through regulation. However, Dewees also argues that there may be a useful role for statutory civil liability as well.

Philippe Rocard and Henri Smets examine the land-use around hazardous installations. They examine the risks incurred by people who live too close to existing hazardous installations. Using empirical evidence of the land-use in France they argue that a ban on building on land near a hazardous installation will result in only a small social loss, while making it possible to reduce the potential loss caused by an industrial accident substantially. Although the loss incurred by a prohibition of building on the land surrounding hazardous installations seems larger than the amounts of direct compensation to be paid to victims, the authors argue that a ban is still efficient because of the high risk aversion of the public to major industrial accidents.

In the third paper Peter Menell addresses the wellknown problem of municipal solid waste. Menell analyses some basic problems of the "municipal solid waste crisis": communities do not utilise an appropriate mix of environmentally sound and economically efficient resource recovery and disposal technologies and consumer's purchasing and disposal decision do not reflect the environmental costs of waste disposal. Therefore he suggests an economic incentive system to internalise the environmental costs of disposal technologies. Although the responsibility for solid waste policy should reside at the local level, Menell argues that a federal government has an important role in regulating the municipal solide waste stream by e.g. promoting recycling markets. He gives several examples of how a policy can be designed to encourage efficient purchasing and disposal decisions by households.

Faure and Skogh present an alternative compensation mechanism for damage caused by nuclear accidents. They argue that the accidents of Harrisburg and Chernobyl showed that the current (statutorily limited) amounts of compensation are not at all sufficient to cover the damages caused by a nuclear accident. They argue that the planned owner should become a member of a mutual guarantee fund, including the plant owners in all the signatory states to the new convention. This mutual pole covers the liability in case of an accident. The states reimburse the liability of the plants in their own country. The consequence is that all plants share the costs of accidents where ever they occur in signatory states. The suggested convention is an ex ante agreement among states and plant owners on the distribution of costs of a nuclear accident. Through this ex ante risk sharing agreement it will be in the interest of the industry to control members by controlling the admission to the pool and internal pricing of safety measures. Thus the accident prevention would also gain a new economic dimension.

Finally, Paul Fenn discusses the impact of fisheries protection activity in the North Sea. He starts with the statement of the European Commission that the catch quotas have not worked and that the mesh size should be increased together with an improvement of the surveillance of vessels. The author analyses the enforcement policy from a law and 
economics perspective, using data for six countries (Belgium, Denmark, France, Germany, Netherlands, U.K.) and two species (codd and haddock). Fenn concludes that there is a weak relationship between current fishstocks and previous total landings. He therefore asks the question whether there are alternative mechanisms for controlling the overfishing problem. The existing regulations restrict the production through the regulation of the average catch per fleet by means of national quota. A complementary policy might be to regulate entry through the management of the fleet-size.

The papers in this volume were anonymously refereed. We thank everyone who provided help by reviewing one of the papers.

Maastricht, February 1992 